\title{
TOWARDS A COMMON EUROPEAN UNION IMMIGRATION POLICY: NAVIGATING A DIFFICULT OBSTACLE COURSE
}

\section{Raluca MOLDOVAN, PhD}

Lecturer, Faculty of European Studies, Babeş-Bolyai University, Romania moldovan.raluca@ubbcluj.ro

\begin{abstract}
The following article focuses on the various attempts that have been carried out to reform the migration and asylum legislation of the European Union. It examines the current perceptions about migration following the 2015-2016 migration and refugee crisis, and then briefly traces the historical evolution of the current legal framework on migration and asylum. My aim is to show how this evolution has reached the point where any attempts to reform the system are primarily driven by security, rather than humanitarian considerations, which makes consensus on any contentious issue very difficult to achieve, a fact highlighted in the third section of the present contribution. The conclusions discuss the limited scope of the latest attempt to overhaul the existing immigration framework, arguing that EU member states are still reluctant to transfer decision-making responsibilities to the supranational level regarding what they consider a matter crucial to their national sovereignty.
\end{abstract}

Keywords: European Union, immigration and asylum policies, migration crisis, securitisation.

\section{Preliminary considerations}

Europe has had a long history of being the final destination that millions of people throughout time have tried to reach in search of a better, more secure, more fulfilling life. As such, migration has been an integral part of the continent's history and, for better or worse, has shaped and transformed it in many different ways. It is clear that migration still shapes and transforms the contemporary European Union - but these days, more often than not, the omnipresent discussions and fears triggered by a "migration crisis" appear to transform it into a rather hostile environment designed to make life difficult for newcomers and to deter others from following suit. The term 
"fortress Europe" has become an ubiquitous phrase in public discourse and the media, and its overuse can make one wonder whether the EU is gradually abandoning the liberal foundations it was built upon and is undergoing not just a migrant crisis, but crisis of immigration policies as well (Fekete 2009; Koopmans et al. 2005). The idea of hospitality and welcoming strangers is now a deeply politicised issue on both sides of the Atlantic, as recent developments in the United States have shown.

While in the past, the relatively steady flow of migrants caused fairly little concern among governments and citizens alike, recent events - particularly the massive wave of refugees displaced by the turbulent events in the Middle and Greater Middle East (especially the Syrian civil war and the aftermath of the Afghanistan conflict) - coupled with fears of terrorism and violence, have given rise to a visible "inward turn" in which Europe is gradually closing its doors and building up fences to keep "the other" out. The European Union legislation concerning migration and asylum reflects this historical evolution: earlier directives were designed to regulate the situation of those who came to European countries with a view to help them adapt and integrate as residents (especially following the large-scale labour recruitment programmes implemented by many Western European states after World War II), or to protect those who were given refugee status (Murray 2017). However, more recent measures and pieces of legislation reflect a clear influence of security concerns that dominate the agenda for EU immigration reform. The main steps in this process are analysed in the second section of the present article, while the third will examine the reasons and consequences of this securitisation of migration in the European Union. The concluding section will discuss the very recent legislative steps adopted in an attempt to kick-start a comprehensive reform and a few possible avenues for the future of the EU immigration system.

The issue of immigration is not likely to disappear from the European political agenda any time soon, given the current predictions concerning population growth, especially in the developing countries of the Global South (which means more and more people might be inclined to leave their countries of origin and become immigrants) (Balch 2016) and the worldwide level of instability and insecurity which often results in significant population displacement. Therefore, the focus of EU immigration policies starting with the mid-1990s had been on deterrence and on reducing the appeal of "pull" factors that represent incentives for migrants to undertake the often dangerous journey bringing them to Europe (such as economic opportunity) or to make life difficult for those who are already there, rather than designing policies to tackle the "push" factors 
(i.e., the reasons why migrants leave their countries of origin), which would mean interfering in the internal affairs of other states (Balch 2016; Jünemann et al. 2017; Collier 2013).

This state of affairs is clearly demonstrated by the exodus of refugees who started arriving in Europe in the spring of 2015, fleeing from the devastation caused by conflicts in Syria, Libya and other parts of Africa and the Middle East. Interestingly enough, most of those who are nowadays fleeing war and destruction come from regions and countries indisputably shaped by the European states' colonial past (De Genova 2017; Geddes and Scholten 2016). These people often chose to embark on a very risky journey across the Mediterranean (which has become a water grave for thousands of them and their often makeshift vessels) in the hope that Europe will offer them a safe haven (Comte 2018); for many of them, this hope never materialised. In many instances, what they found instead was a hostile environment seemingly built on the principle of "enforcement by attrition" illustrated by an increasing use of deportation and detention of undocumented migrants (Balch 2016). This fact points to an growing level of public anxiety over immigration in both Europe and North America, evident in the figures revealed by the 2016 Transatlantic Trends Survey; these uncover an evident "perception-reality" gap regarding the number and types of immigrants; in other words, the levels of fear reported are not directly correlated to actual immigration realities and they are rather based on a kind of "imagined immigration" and on how it is perceived by the public (Balch 2016). This perception is often influenced by political discourse, especially the one coming from the far-right end of the spectrum, in which there is a clear "us" versus "them" dichotomy between the prosperity, rights and freedoms of European citizens and the barbarity of those who come to threaten this way of life and to partake in undeserved benefits. ${ }^{1}$ The main targets of this "politics of fear" type of discourse (not confined to the realm of right-wing parties alone) are immigrants of Muslim origin who are seen as dangerous, subversive and backwards (Khory 2012). The same voices also habitually argue against the possibility of a uniform EU-wide immigration system, as they see immigration as a primarily

${ }^{1}$ Given the current international political climate, much of the public hostility and fear is directed against immigrants of Muslim origin, who are seen as incapable of integration and prone to violence. In fact, former UK Prime Minister David Cameron argued at a security conference in Munich that the failure of Europe's Muslims to assimilate the values of host societies greatly increased the chances of terrorist attacks throughout the European Union (Khory 2012). This attitude is symptomatic for how many European leaders see Muslim identity as homogenous, transnational and profoundly resistant to change and integration. As early as 2011, German chancellor Angela Merkel was very clear about the failure of the so-called "multicultural policies" because of their over-emphasis on difference and diversity and too little focus on commonality (Geddes and Scholten 2016; O’Nions 2014). 
domestic concern where state sovereignty should rule supreme. This attitude has so far paid off for far-right parties from the UK to Poland and Hungary, and from the Netherlands and Germany to Italy, judging by their electoral success and the support they enjoy among large segments of the population who embrace their challenge against the liberal political establishment (Jünemann et al. 2017). ${ }^{2}$ One clear consequence of this fraught political and social environment is the emergence of the immigrant-native and immigrant-state conflict. While before 2015, these two types of conflicts were mainly determined by economic conditions and the scarcity of resources in any given region, nowadays fear and reluctance stemming from ethnic differences are the main factors in the relations between migrants and citizens of host countries, while preventing migrants from accessing welfare benefits has taken a somewhat secondary position (Dancygier 2010; Korkut et al. 2013).

Over the last two decades, the European Union has tried to persuade states to harmonise their immigration and asylum policies, while at the same time, gradually adopting measures to manage and control migration flows, despite mounting evidence of a looming demographic crisis triggered by declining birth rates and an aging population (Fekete 2009; Lazaridis 2015). As a result, the skills-based recruitment programs for foreign workers (such as the Blue Card Directive) have been rather limited in scope and have not yielded significant results. In turn, EU member states have been reluctant to support a common immigration and asylum system primarily because of the impact of large-scale migration on three fundamental pillars of the nation-state: sovereign control over external borders, regulating the right to receive citizenship, and national identity (Koopmans et al. 2005). The rather limited paths of arriving legally in Europe have driven many migrants to resort to alternative means of making the journey, thus swelling the numbers of those labelled as illegal, irregular or undocumented migrants and making illegal migration a key feature of contemporary global migration (Düvell 2006).

The arrival of significantly large numbers of non-European, mostly Muslim migrants seems to have affected the unity of Europe by bringing once more to the surface the old fault lines between east, west and south (Samaddar 2017), and this is one of the reasons why consensus on an efficient set of immigration rules and policies has proven so difficult to achieve; other reasons include

\footnotetext{
2 One piece of evidence in this respect is the result of the Brexit referendum in the UK. Anti-immigration discourse and highlighting the dangers posed by migrants were core components of the "Leave" campaign's message (Comte 2018).
} 
differences in the size and composition of the migrant population in different EU states and varied attitudes towards immigration and asylum (Wiesbrock 2016). As it turns out, it is currently much easier to erect physical barriers than to sit at the negotiation table: if this trend keeps up, Europe might soon have more borders than it did during the Cold War, with Greece and Bulgaria constructing fences on the border with Turkey, Hungary sealing off its border with Serbia, and Sweden fencing off platforms at Kastrup railway station in order to stem the flow of migrants from Denmark across the Oresund bridge (The Economist 2016).

\section{European Union immigration law in historical perspective}

The various meanings of citizenship (as a status, as a relation between political authority and citizens, or as a process for inclusion and exclusion) have been at the core of immigration politics in Europe. ${ }^{3}$ EU migration policies include three major aspects: free movement for EU citizens within the single market, asylum policies, and immigrant policies that offer some social and legal rights to legally residing third country nationals (Geddes and Scholten 2016). In drafting immigration policy, the EU Commission and Parliament have tended to adopt a less securitised view on immigration, but their efforts have often been thwarted by national governments (Demeny 2006; Abdou 2016).

If, for many decades before World War II, Europe was an area of emigration, this situation changed dramatically after 1945, with successive waves of immigration altering the composition of population in various European states: between 1945 and 1975, most arrivals were done through labour recruitment programs, while after the mid-1970s, the focus shifted to family reunification, then to refugees and asylum seekers after 1990, to highly-skilled migrants from the 2000s onwards

${ }^{3}$ I believe it useful to introduce here a distinction between immigration policies (dealing with regulation of migratory flows, border controls, the admission of foreign nationals, etc.) and immigrant policies, combining all the legal measures and administrative practices that govern the life of an immigrant in the host country (Martiniello 2006). 
and, once more, to refugees starting with $2015 .{ }^{4}$ The present section will focus on an overview of the main tenets of the EU's immigration regime, both in terms of migration for economic, study or family reunification purposes and asylum.

The postwar European economic boom led to a growing demand for labour force recruited mainly from developing countries (often former colonies) and Southern Europe. This system was regulated by association agreements and guest worker programmes, such as the one signed between Germany and Turkey. All these schemes were based on the idea of temporary migration, although at first the issuing of labour and residence permits was done on a fairly liberal basis (Martiniello 2006). However, the economic recession at the end of the 1960s and the first major oil crisis in 1973 marked the start of European legislation meant to restrict the flow of foreign workers so as to avoid a growth in domestic unemployment. One unintended consequence of these restrictions was that many temporary workers, for fear they might not be able to return if they went back to their countries of origin, became permanent settlers; in turn, over time, this led to an increase in the number of family migrants (Wiesbrock 2016). If, at first, the entry and residence conditions of migrant workers fell entirely in the responsibility of national governments, beginning with the late 1970s one can notice a gradual transition towards more cooperation among the EEC members in matters of migration and asylum policies. For instance, in 1968, the EEC adopted the first legal regulations concerning the freedom of movement of European workers (Council Directive 68/360/EEC; Martiniello 2006).

One of the first major European decisions affecting migration was the 1986 Single European Act, which created a single internal market where borders were abolished and free movement of people, goods, services and capital was guaranteed; consequently, this implied a closer cooperation in the area of domestic affairs, including migration and asylum policy (Wiesbrock 2016; Abdou

\footnotetext{
${ }^{4}$ Despite these general continental trends, many European countries have had different experiences with migration: for instance, Greece, Italy, Portugal and Spain had been major sending countries before turning into preferred destinations in the late 1970s and 1980s; nowadays, these Southern EU members are among the states with the largest migrant populations, primarily due to their Mediterranean location (Wiesbrock 2016; Roos 2013). Conversely, countries like Germany, Austria, Sweden and Denmark traditionally relied on guest worker programmes to address their labour shortages in the first three postwar decades, while former colonial empires such as Britain and France welcomed unskilled labour migrants from their former colonies. These diverse experiences account for a variety of approaches to immigrant integration, from forced assimilation (France) to multiculturalism (The Netherlands, Sweden) and segregationism (Germany, Austria). In terms of language, Britain and the Netherlands prefer the phrase "ethnic minorities", Germany refers to immigrants by their national origin, whereas in France one is reluctant to speak about immigrant minorities at all (Geddes and Scholten 2016).
} 
2016). Moreover, the 1985 Schengen Agreement stipulated the abolishment of internal border controls among the original signatories of the 1957 Treaty of Rome (France, Germany, and the Benelux countries) (Abdou 2016). The field of internal affairs was transformed into one of European policymaking after the signing of the Maastricht Treaty in 1992; ever since, progress in adopting a common European framework has been slow, given the reluctance of member states to relinquish control over matters considered to be at the heart of state sovereignty. Before the 1997 Treaty of Amsterdam, the EU was not able to adopt legally binding directives in the area of justice and home affairs, but the new treaty established an area of "freedom, security and justice" and gave the European Council the clear legal basis to adopt measures concerning asylum and immigration, including illegal immigration and the repatriation of undocumented migrants (Wiesbrock 2016, p. 163; Abdou 2016). The 2009 Lisbon Treaty abolished the former pillar structure and unified all matters of visas, asylum and immigration (formerly under the first pillar) with those of police and judicial cooperation (formerly under the third pillar); it also expanded the co-decision procedure to cover measures on legal migration (Abdou 2016).

Since the adoption of the Treaty of Amsterdam, the EU has developed its immigration and asylum policies according to five-year multi-annual programmes. Following the European Council meeting at Tampere in October 1999, the leaders of the member states agreed on the adoption of the so-called "Tampere Programme" through which the EU could adopt measures in four policymaking fields pertaining to immigration and asylum: partnerships with countries of origin, a common European asylum system, fair treatment of third country nationals and management of migration flows (Wiesbrock 2016; Balch 2016). The initial momentum following the Tampere Council was stopped by the terrorist attacks of 9/11, which confirmed, to a certain extent, that the vulnerability of the western world stemmed from porous borders, generous entry policies and violation of terms of access (Lazaridis 2015); afterwards, the focus of EU policies shifted to combating illegal immigration and strengthening border controls, which further delayed the adoption of common policy instruments.

The 2004 Hague Programme on migration was much more security-focused than its predecessor, also considering the fact that Europe itself was being confronted with its own terrorist threats (Eisele 2016); it also provided for the cooperation with UNHCR to improve the protection of refugees. In 2005, the EU heads of state and government launched the Global Approach to Migration designed to ensure an in-depth dialogue, close cooperation and partnerships with third 
countries in matters of migration and asylum. ${ }^{5}$ This initiative became the Global Approach to Migration and Mobility (GAMM) in 2011, which also covered international protection and asylum for third country refugees in the aftermath of the Arab Spring (Eisele 2016). A key feature of GAMM are mobility partnerships, i.e., non legally-binding declarations between various EU member states and third countries, based on the specific needs of the third country and the EU's interests in the region. ${ }^{6}$

In July 2008, former French president Nicolas Sarkozy proclaimed the European Pact on Immigration and Asylum, endorsed by the European Council two months later. The document includes several Commission proposals for a common EU immigration policy and puts forward five basic commitments: managing legal migration, a renewed fight against irregular migration, a common European asylum system, effective border control through FRONTEX and cooperation mechanisms with third countries. The Commission established a system for monitoring the implementation of the pact based on input from member states (Eisele 2016; Korkut et al. 2013).

In December 2009, the EU Council adopted a new multi-annual policy programme designed to cover the period 2010-2014, the Stockholm Programme, whose aim was to balance security concerns with respecting fundamental rights and freedoms guaranteed by the European Charter of Human Rights. The programme highlights the need to fight against illegal immigration and transborder criminality, while at the same time facilitating legal access channels to the EU territory (Wiesbrock 2016; Eisele 2016).

The current legal basis for the regulation of migration and asylum policy in the European Union is Title V of the Lisbon Treaty (Treaty on the Functioning of the European Union). The EU seeks to promote economic liberalisation and free movement for its own citizens, while at the same time strictly regulating the entry of non-EU nationals; this became evident during the 2015-2016 refugee crisis, when several EU states reinstated ad hoc border controls to stop the flow of people across the Union (Geddes and Scholten 2016). Despite adopting a number of instruments regarding the two policy areas, member states are still the main deciding factors in matters of admitting

\footnotetext{
${ }^{5}$ Under GAM, the first priority was given to the Mediterranean region and to Africa, and in 2007 the agreement was expanded to cover the eastern and south-eastern regions of Europe, including Turkey, the West Balkan states, the European Neighbourhood Policy partners in Eastern Europe and South Caucasus, as well as Middle Eastern ENP partners, Central Asian countries and other Asian sending states. The particular emphasis of the GAM was fight against illegal immigration.

${ }^{6}$ So far, mobility partnerships have been concluded with Cape Verde, Moldova, Georgia, Armenia and Morocco.
} 
foreigners and regulating the conditions of their stay. So far, relatively little has been accomplished in the development of a common immigration policy that would regulate the conditions for admission and residence, for issuing visas and long-tern residence permits, the rights of legal thirdcountry nationals and freedom of movement and residence in another member state. The most important directives adopted until now regard family reunification (September 2003; Council Directive 2003/86/EC), long-term residence status (November 2003; Council Directive 2003/109/EC), students and researchers (December 2004; EU Directive 2016/801), and highly skilled workers (May 2009; Council Directive 2009/50/EC) (Lyons and Huegle 2010). All these directives have come under criticism for various reasons.

The family reunification directive merely outlines minimum standards, thus grating member states a wide margin of discretion on how these standards should be incorporated into national law; these may impose age and financial resources and integration (such as a language or civic knowledge test) limitations on third-country nationals who wish to join immediate family members residing in an EU country, which, in turn, may contravene to article 8 of the ECHR that guarantees the right to family life (Roos 2013). The long-term residence status directive grants third country nationals with a legal and continuous five-year residence in EU countries the right to long-term residence provided some conditions are met, such as stable and sufficient resources and health insurance (Geddes and Scholten 2016; Roos 2013). Those who qualify are also granted protection against expulsion, access to employment and social security. However, the directive includes considerable restrictions to the extent of rights granted to long-term residents compared to the rights given to internal migrants who are citizens of EU member states.

The directive on students and researchers defines the rights of third country nationals who were accepted by a higher education institution in an EU member state, such as the right of free movement to other member states and the right to part-time employment (Roos 2013). The admission of researchers from outside the EU is also facilitated, especially if they are involved in research projects with EU partner institutions. Criticism against this directive stems from the fact that, under its current provisions, universities and research organizations are given a key role in the admission procedure (Wiesbrock 2016).

Regulating economic migration has probably been the most controversial aspect of the common EU policy on migration, precisely because the admission of foreign workers is a very sensitive issue at national level, where oftentimes they are perceived as a threat to the job security 
and income of state citizens. In 2007, the European Commission introduced a "sectoral approach" legislation meant to regulate the entry and residence of distinctive categories of labour migrants: highly skilled workers, seasonal workers, remunerated trainees and intra-corporate transferees (Roos 2013). In December 2011, a directive establishing a unified application procedure for single work and residence permits for third country nationals and a common set of rules for third-country workers legally residing in a member state was adopted.

The directive on highly skilled workers, known as the Blue Card directive, was adopted in May 2009. Those who are eligible under its provisions receive a residence permit for between one and four years and a considerable minimum salary, yet it does not establish a firm legal clarity, certainty and predictability (given that this is a temporary scheme) in terms of national legislative procedures (Wiesbrock 2016; Geddes and Scholten 2016; Lazaridis 2015; Orrenius and Zavodny 2016). Member states still maintain control over the number of highly skilled workers on their territory. Two more recent EU legal instruments on labour migration are the directives on seasonal workers (February 2014) and intra-corporate transferees (May 2014). The former is expressly aimed at preventing temporary workers from becoming permanent, while giving member states considerable discretion concerning the volume of admission and the rejection of applications. The latter makes it easier for multinational corporations to temporarily transfer highly skilled employees to branches inside the European Union.

These directives have been criticised from a human rights perspective because they seem to be based on an "utilitarian approach" to immigration that considers the economic needs of the receiving country (Roos 2013). Moreover, the provisions they include are unlikely to make the EU an attractive destination for highly skilled workers, students and researchers, because their stay is limited in scope and they enjoy a small number of rights. Nevertheless, the fact that member states were able to commonly agree on these six directives, despite immigration being an unlikely case of EU integration, should represent a solid starting point for future legislative regulations and may point to the fact that, even though the nation state is not disappearing, it is changing (Roos 2013; Abdou 2016). 
One of the fundamental objectives of a common European immigration policy is to combat the threat of illegal migration ${ }^{7}$ by developing an effective removal and repatriation procedure and discouraging illegal employment. This policy shift is especially visible after 2001, when migration ceased to be a matter of "low politics" and became instead a question of "high politics involving national security" (Lazaridis 2015, p. 34). So far, the main EU instruments dealing with illegal migration have been the Return Directive, readmission agreements and the sanctions against employers directive (2009/52/EC). The Return Directive was adopted in December 2008 (2008/115/EC) and provides minimum standards and procedures at EU level for returning the immigrants found illegally staying on the territory of a member state to their country of origin or to a country of transit. Those who fail to voluntarily comply with the return decision of a member state are subject to forcible removal or detention, accompanied by an entry ban of up to five years. This directive has been heavily criticised for its minimum standards approach that grants a lot of discretion to member states (Wiesbrock 2016).

Readmission agreements are concluded with third countries based on the reciprocity of admitting their own nationals who do not fulfil the conditions for entry or residence on the territory of the requesting state (Eisele 2016). So far, the EU has concluded readmission agreements with numerous states; however, these instruments are controversial, as they raise concerns about the human rights protection of the individuals who are readmitted, because the EU effectively hands over responsibility in this area to a third party, especially since the agreements contain no provisions on supervision or monitoring of they way in which the retuning migrants are treated.

The directive on sanctions against employers was adopted in June 2009 and contains a general prohibition against employing illegally staying third country nationals. Thus, the issue of controlling access to employment is given over to employers and may discourage them from employing third country nationals for fear these might present them with false work permits and identity papers.

Another long-standing aim of EU policies has been strengthening external border control and surveillance, especially considering that the Schengen system means that internal borders among

\footnotetext{
${ }^{7}$ Illegal immigration can take a variety of forms, from illegally entering the territory of a member state by sea, land or air, using false documents or organised crime networks to entering with a legal visa and overstaying, or to unsuccessful asylum seekers who fail to leave the EU after receiving a final negative decision. For more details about the various types of illegal migrants, see Düvell 2006, pp. 15-16.
} 
its member states are abolished. The responsibility for protecting the external frontiers of the Schengen system has been given over to FRONTEX, an agency that supports member states in securing external frontiers, trains border guards and assists in joint return operations, but can only act upon request, or in cooperation with member states (Lazaridis 2015). The surveillance of the Schengen borders is done through the Schengen Information System (SIS I and II) and Visa Information System (VIS) (Geddes and Scholten 2016). ${ }^{8}$

As far as the asylum policies of the European Union are concerned, their legal basis is the 1951 Geneva Convention on the Status of Refugees; over the past three decades, the EU has developed a system designed to ensure the protection of those who arrive in Europe as refugees and qualify for receiving asylum (Cherubini 2015). Initially, this system was one of intergovernmental cooperation, but later on, EU institutions were given more responsibility in the field of asylum policy (Karamanidou 2015). This system was tested to the limit during the 2015-2016 refugee crisis and it has revealed a number of significant flaws. Following the massive influx of people coming into Europe in the period in question, there was a relatively widespread perception among European citizens that the newly arrived were little more than economic migrants who would not qualify for entry under the regular immigration system and was thus bypassing them by using the asylum route (O’Nions 2014). ${ }^{9}$

The Treaty of Amsterdam moved asylum from the third to the first EU treaty pillar, while the Treaty of Lisbon definitely communitarised the asylum policy field (Cherubini 2015); since its adoption, a number of legislative pieces have been passed, mostly based on the minimum standards approach and burden-sharing among EU member states. As in the case of immigration legislation described above, the main focus of these measures was to prevent irregular migration, the abuse of the asylum system and the strengthening of the borders. The common European asylum system was to be introduced in two stages: first, the national legal frameworks would be harmonised and then, higher common standards of protection at the level of the EU would be adopted (Wiesbrock

\footnotetext{
${ }^{8}$ SIS aims at identifying people who are a potential threat to the security of the EU by allowing member states to exchange information about third country nationals considered inadmissible, while the VIS is a system for the exchange of visa information among member states. The EU visa policy operates with a "positive" and "negative" list, the latter containing a large number of mostly Muslim and developing states; this has been criticised as a measure of keeping the "undesirables" out (Wiesbrock 2016).

${ }^{9}$ If one is to admit this assumption to be true, then it begs the question, why did all these people wait until 2015 to come to Europe, if they were not refugees forced to flee war and conflict, but simply migrants in search of a better life?
} 
2016). The Tampere conclusions also included a commitment on the part of member states towards the establishment of a Common European Asylum System, a commitment reaffirmed by the Hague Programme (Martiniello 2006; Fekete 2009; O’Nions 2014; Geddes and Scholten 2016). The current CEAS has four components: the Dublin III Regulation, minimum standards for reception and detention, minimum standards for processing asylum claims, minimum standards for granting or withdrawing refugee status (Balch 2016). Although the harmonisation of asylum policies was officially declared complete by 2012 , recent events have revealed the need for a reconsideration of current asylum regulations.

The main pillar of international refugee law is that of non-refoulement, which means that neither refugees nor asylum applicants can be returned ("refouled") to any territory (including that of their country of origin) where their life or liberty would be endangered (Craig 2013; O'Nions 2014; Cherubini 2015; Hassouri 2017). ${ }^{10}$ The most important EU legislative instruments regarding asylum policies include the Dublin Regulations (the first one signed in 1990, it entered into force in 1997), the directive on the reception of asylum seekers, a directive on the qualification of refugees and another on procedural standards, all of which have gone through several revisions (Vink 2005).

In June 2013, the EU adopted an asylum package containing some changes to the asylum legislation (Wiesbrock 2016). This package includes the Dublin III regulation replacing the Dublin II Convention of February 2003, which determines the state responsible for processing asylum applications and is meant to prevent the secondary movement of asylum seekers through Europe (Martiniello 2006; O'Nions 2014; Cherubini 2015; Geddes and Scholten 2016): according to its legal provisions, an asylum seeker must file a claim with the state authorities of the EU member state in which he/she first arrived. The purpose of this regulation is to prevent the so-called "asylum shopping" by which asylum applicants would seek to file their claim in the EU member state with the most favourable asylum system (Craig 2013; Cherubini 2015). This system, however, is not without criticism: as the 2015-2016 events have shown, the southern European countries (primarily Greece and Italy) which, under the Dublin regulations, would have been responsible for processing hundreds of thousands of asylum applications for the people arriving on their shores, were simply too overwhelmed and often allowed refugees to travel further without examining their asylum

${ }^{10}$ This principle is enshrined both in the 1951 Refugee Convention and in the European Charter of Human Rights. 
claims (Murray 2017) ${ }^{11}$ so that their case would be examined in another member state where their request would be treated according to different standards. ${ }^{12}$ If this should happen, the state where the asylum claim is filed has the obligation to transfer the applicant to the state in which he/she first arrived, so that their application can be processed there - which means that the states least able to deal with massive numbers of refugees find themselves placed under a disproportionate burden (O'Nions 2014). This situation raised serious questions about the principle of uniform processing of asylum claims throughout the EU (Wiesbrock 2016). However, unlike the previous Dublin regulations, the 2013 one expressly stipulates that a member state cannot transfer a person to another member state if there is a risk the subject would endure inhumane or degrading treatment. ${ }^{13}$

A directive adopted in January 2013 is the one on the minimal standards for the reception of asylum seekers, applicable to anyone who files an asylum claim in the territory of a member state (2013/33/EU). Eligible asylum seekers have the following rights: receiving information about their benefits and obligations they must observe while their application is processed; receiving a document certifying their status; maintaining family unity; receiving medical attention on public health grounds; access to education for minor children; freedom of movement within the territory of the state; conditional access to employment - although this right is not universally guaranteed, but depends on national regulations (Wiesbrock 2016; O'Nions 2014; Cherubini 2015). ${ }^{14}$ The directive also contains more detailed rules on the detention of asylum seekers, but fails to establish uniform conditions for detention: for instance, detention for asylum seekers in Germany is an exceptional occurrence, while all claimants arriving in Malta are routinely sent to detention centres, except for those with special needs.

${ }^{11}$ In fact, five southern European countries, Cyprus, Malta, Greece, Italy and Spain have called for the urgent revision of the Dublin system to include a suspension of transfers to states facing considerable pressure on their national asylum systems (Geddes and Scholten 2016).

${ }^{12}$ An illustration of this reality is the fact that, prior to the 2015 refugee crisis, the percentage of asylum claims approved annually was $84 \%$ in Finland, 51\% in the Netherlands and only 2\% in Spain (Cherubini 2015).

${ }^{13}$ During the 2015-2016 crisis, about $80 \%$ of all refugees arrived through Greece, where the functioning of the asylum system was known to be deficient, especially as far as reception conditions and processing procedures were concerned. This fact reinforced the idea that main aim of the Dublin system is the transfer mechanism between states and a deflection of refugees, not a fair determination of protection needs (O’Nions 2014; Craig 2013).

${ }^{14}$ The directive allows a one-year delay in access to the labour market; after this period, the member state must grant employment access subject to national conditions. 
The revised Procedures Directive, also adopted in June 2013 (2013/32/EU), stipulates minimal procedural standards for the processing of international protection applications, rules and guarantees for examining asylum claims, as well as procedures for the withdrawal of refugee status, which must be based on a single procedure. Procedural guarantees include the right to access the procedure, to legal assistance, to remain on the territory of the member state until a decision is made and receive a motivated decision on the asylum claim (Cherubini 2015). The most problematic aspect of this directive is that it includes the concept of so-called "safe countries" where the applicant might be returned to if he/she receives a negative decision, i.e. any country to which the asylum seeker might have a connection and that respects the principle of nonrefoulement and fundamental human rights. Moreover, member states have the right to refuse the examination of an asylum claim if the applicant comes from a country designated as safe by the European Council or by member states, which are allowed to draft their own lists of safe third countries (O'Nions 2014). ${ }^{15}$ In practice, the problems stems from the fact that there is no procedure to review the classification of a third country as "safe" (Wiesbrock 2016).

The Qualifications Directive was adopted in 2011 (2011/95/EU) and it sets out the criteria for recognizing persons in need of international protection and the type of protection granted. It also includes a distinction between a refugee and someone eligible for subsidiary protection, as the two types are granted differential treatment; the definition of a refugee is borrowed from the 1951 Geneva Convention, while a person eligible for subsidiary protection is "any other third country national or stateless person in respect to whom there are substantial grounds to believe that the person would face real risk of suffering serious harm if returned to his or her country or origin or country of habitual residence" (Wiesbrock 2016, p. 179).

In recent years, there have been sustained efforts, especially on the part of individual member states, to export or externalise the burden-sharing regarding refugees beyond the borders of the Union through various arrangements such as readmission, external processing and resettlement (Karamanidou 2015; Geiger 2016). However, if the responsibility for determining refugee status

15 The current European list of safe countries includes Albania, Jamaica, Republic of Korea, Kosovo, Macedonia, Moldova, Serbia, Montenegro, Brazil, Ecuador, Bolivia, South Africa, Ukraine, India, and Bosnia Herzegovina, Mauritius, Peru, Ghana, Nigeria, Gambia, Malawi, Liberia, Mali and Sierra Leone. One of the main objections against the practice of member states creating their own lists of safe third countries or safe countries of origin is that it affords them too much discretion. 
and processing asylum claims is transferred to a third country, this raises serious concerns in terms of accountability and the protection of human rights. Readmission agreements are designed to ensure cooperation over the return of illegal migrants and thus combat illegal immigration and reinforce border control. External processing, modelled on the Australian "Pacific Solution", means processing asylum claims away from the destination state, which keeps both the applicant away from the host state and the latter away from its legal obligations. Resettlement has been promoted by the EU Commission and the UNHCR as a lasting solution to refugee protection: under this scheme, refugees can be transferred to another state identified on the basis of family, educational or cultural ties to the applicant or other demonstrable links (Fekete 2009; O'Nions 2014).

While more progress has been achieved, in comparison to immigration policy, in creating a common European asylum policy, there is still some way to go before the full implementation of uniform procedures (Cherubini 2015; Craig 2013); as it is, the system is still undermined by state practices that continue enjoy a wide margin of discretion largely focused on preventing irregular migration (which shows that, in the states' view, asylum is just another channel of irregular migration), since most, if not all the directives adopted so far fail to detach refugee protection from immigration control and therefore reinforce the securitization of asylum policy and the deflection of refugees rather than their acceptance (Craig 2013). A truly efficient asylum policy in the European Union needs to be liberated from the current state in which it serves two masters, often with opposed views and interests.

\section{The contemporary securitisation of EU migration policy}

Regarding migration as having security implications has always been a characteristic of European Union policies, especially after the Schengen Agreement (where it appeared rather marginally), which abolished the internal borders among the signatory states, entered into force (Squire 2015), but it was only after 9/11 and the subsequent waves of terrorist attacks carried out throughout western Europe that it has emerged as a prominent concern behind any attempt to reform the European immigration system whose failings have been highlighted by the 2015-2016 migrant and refugee crisis. The framing of migration in terms of security influences several political issues, such as the one of citizenship, the relationship between EU nationals and third country nationals, and the relation of the EU to its external environment (Munster 2009). The 
following section will examine how migration has been securitised in the past few years and what its contemporary implications are (Karamanidou 2015).

The constant calls for a greater securitisation of migration policies, especially coming from increasingly popular far-right political parties, has not created a safer Europe, but rather a society that lives in constant fear, never knowing where the next attack might come from, a society where ethnic groups (especially those of Muslim origin) feel scapegoated and excluded (Lazaridis and Wadia 2015; Amelina et al. 2016). The European public discourse is practically dominated these days by a constant reiteration of the connection between migration and terrorism, based on the fact that most of the perpetrators of recent terrorist attacks in Paris, Brussels, Nice, Berlin, etc. were European nationals of immigrant descent (Squire 2015; Pickel 2018; Murray 2017). ${ }^{16}$ An indicator of how influential this type is discourse is lies in the fact that recent Eurobarometer polls have consistently shown that European citizens consider immigration to be the most important issue facing the EU in all member states; a majority of $58 \%$ of all respondents listed immigration among their top two concerns (Welsh 2016), which basically shows that what started out as a temporary migrant crisis has now become the new normal across the EU.

The three main pillars of this type of discourse are "bogus' asylum seekers, illegal migrants, and criminals, all of whom profit from Europe's liberal policies to undermine the western way of life by affecting national identity and threatening the economic, social and political stability of the host state (Lazaridis 2015; Martiniello 2006). The criminalisation of migration is visible in the recourse to traditional criminal law procedures against migrants, such as surveillance and detention, and through various mechanisms of prevention and pre-emption (Mitsilegas 2015). The portrayal of migrants in the political discourse, as well as in the media, has also marked a renewed significance of the religious factor in a previously strongly secularised Europe (Schmiedel and Smith 2018). ${ }^{17}$

There are four major scenarios according to which the migration-security nexus threat plays out: first, fear of a massive flux of irregular migration that puts enormous pressure on the borders

16 The November 2015 Paris attacks and the subsequent March 2016 Brussels attacks were linked to predominantly the Moroccan and Algerian Molenbeek district in Brussels, labelled by many European newspapers as „Europe's jihadi central” (De Genova 2017).

${ }^{17}$ This revival, however, is rather ambiguous, because, on the one hand, Christian arguments have been invoked to save the identity of Europe by accepting migrants, and on the other, to save the identity of Europe by rejecting them (Schmiedel and Smith 2018). 
of the receiving state; second, fear of a major imbalance between immigrant and existing minority groups in the host country that are often exaggerated to create the impression that migrants profit from the welfare policies of the host state; third, fear of the inability of the migrants to integrate, which leads to the creation of "parallel societies" with little to no interaction with the mainstream; fourth, fear of terrorist attacks (Lazaridis 2015). Moreover, illegal migrants may also be seen as burden for the relations between their country of origin and the host country, since they might be instrumentalised by their host government against the sending government (Martiniello 2006; Volkel 2017).

Recent developments in the field of asylum and migration policies have been guided almost exclusively by security concerns: the creation of FRONTEX, ${ }^{18}$ the SIS I and II systems, the VIS, the EURODAC (the EU asylum fingerprint database), the externalisation of asylum and migration policies ${ }^{19}$ through third country agreements under GAMM are all examples of viewing migration through the lens of security and the threats it might pose (Karamanidou 2015; O'Nions 2014; Mitsilegas 2015; Scheel 2017). ${ }^{20}$ The practices of detention and deportation of migrants who are already within the EU territory single them out as threats that must be removed so that order and security can be restored; both practices have a long history of controlling "undesirable" populations and groups and casting them as political and social enemies. ${ }^{21}$

${ }^{18}$ By engaging in joint operations of border surveillance and control, deportation flights, research and risk analysis, all of which are central to the securitised management of migration in the EU, FRONTEX becomes part of what amounts to "preventive refoulement" operations.

${ }^{19}$ One relevant example of externalisation is the EU-Turkey refugee deal signed in March 2016, by which, for every irregular migrant sent back to Turkey, the EU undertakes the obligation to host a corresponding number of qualified asylum applicants. So far, this agreement has been successful in reducing the immigrant flood to a trickle, but it has also been beset with problems and mutual accusations of breaching the terms of the deal. The final text of the EU-Turkey deal signed in March 2016 is visibly rooted in the idea that undocumented migrants are primarily seen as a security threat rather than a humanitarian crisis.

${ }^{20}$ Securitisation is a process that involves both discursive elements and social practices: according to the Copenhagen School, securitisation designates various issues as security threats through "speech acts" implying the shared understanding among political elites and the public as to what constitutes a security threat; this threat is based on the construction of opposing identities - in this case, an "us" (European citizens) versus "them" (migrants) locked in violent battle for survival (Munster 2009; Karamanidou 2015).

${ }^{21}$ The detention and deportation regime has been expanded after 2000 and a 2001 Directive on the Mutual Recognitions of Decisions of the Expulsion of Third Country Nationals (2001/40/EC) allowed the reinforcement of an expulsion decision by one member state on the territory of another member state (Karamanidou 2015). The detention and deportation of migrants stem from a securitisation logic that places their subjects outside the legal protection afforded to other categories of people and, rather than being an exceptional occurrence, they have become the norm in the securitised approach to migration. 
Removing migrants from the EU territory appears to be a political priority for EU member states, because they wish to be perceived as being in control of their borders - a fact made clear by the Return Directive discussed in the previous section, which aims to speedily remove migrants, while at the same time legitimising the criminalisation of migration by allowing member states to detain migrants (Mitsilegas 2015; Balch 2016). As such, more often than not, this highly securitised approach might come in contradiction with the EU as an "area of freedom, security and justice" and with human rights commitments (Munster 2009). Moreover, the considerable recent financial investment in border protection might not actually reduce the number of migrants who intend to cross them, but have the opposite effect: it will probably make them resort to even more dangerous options to find a way through, options that are reduced to clandestine and increasingly criminalised routes. ${ }^{22}$ This fact places refugees and asylum seekers in virtually the same category as economic migrants and complicates the differentiation among categories within these mixed migration flows (Welsh 2016).

The many thousands of death among migrants who tried to cross the Mediterranean in 20152016 bear witness to this argument and have prompted Brussels officials, invoking humanitarian concerns, to find a solution to this problem ${ }^{23}$ while at the same time trying not to jeopardize the security of the EU's external borders, which has been a point emphasised time and again by the governments of the member states (Völkel 2017; Geddes and Scholten 2016). These attempts have revealed a significant difference between migration-related practices (mostly supported by member state representatives in the EU Council) and migration-related discourses (mostly coming from the Commission and the European Parliament).

\footnotetext{
${ }^{22}$ For instance, while it is true that the EU-Turkey deal considerably reduced the number of migrants coming via the Aegean Sea and Turkey, there was a visible increase the number of migrants (and deaths) on the dangerous route from Libya to Italy (Traub 2016).

${ }^{23}$ The EU has launched a series of measures to prevent human trafficking networks from bringing more migrants into Europe and to save those who are in distress: the 2014 FRONTEX Triton mission and the EU Naval Force Operation Sophia (established after 700 migrants drowned off the coast of Italian island Lampedusa); while thousands have been saved through these missions, these search and rescue acts may have also encouraged the very actions they were trying to combat and prompted migrants to try crossing the sea in unsuitable vessels, knowing there is a good chance of them being saved by EU patrolling ships. Moreover, faced with the growing number of deaths caused by the perilous Mediterranean crossing, German chancellor Angela Merkel announced in September 2015 that the Dublin system was suspended and that Germany would welcome any refugees arriving in the country, regardless of the number. This added to the state of chaos, because many hundreds of thousands of migrants tried to make the journey north by crossing several EU member states where their presence caused significant political and social turmoil (Schmiedel and Schmidt 2018; Murray 2017).
} 
The European Asylum Directive and the European Asylum Support Office have proven rather inefficient in combating the practical view that access routes to Europe should be kept as narrow as possible, mainly because most decisions on migration policy are made in the Justice and Home Affairs Council consisting of the member states' ministers of interior and justice (Völkel 2017). A case in point is the recently adopted European Agenda on Migration of May 2015, whose first two pillars to improve migration management express a point of view clearly rooted in securitisation: "reduction of incentives for irregular migration and improvement in border management with the aim of securing borders and saving lives". The other two main ideas are the strengthening of the common EU asylum policy and establishing new approaches to legal migration (Völkel 2017, p. 87).

Following the 2015-2016 refugee and migrant crisis, many EU member states (Germany, Austria, the Czech Republic, Slovakia, the Netherlands, Belgium, France, Spain, Italy and Sweden) started reintroducing temporary border controls that undermined one of the major achievements of European integration, the Schengen agreement (De Genova 2017; Lehne 2018). In addition, in September 2015, the countries of the Visegrad Group (Poland, Hungary, Czech Republic and Slovenia) vehemently opposed the scheme of relocating 160,000 asylum seekers from Greece and Italy to other EU countries based on a quota system, which meant that this measure was very difficult to implement and only 20,000 people of the total refugee number were actually relocated (Geddes and Scholten 2016; Grigonis 2016). This measure was part of a wider set under the European Commission's Agenda for Migration, proposed in May 2015, designed to comprehensively deal with the migration crisis; this included the proposals for the creation of a European Border and Coast Guard (to supplement the existing EUROSUR, European Border Surveillance System, created in 2013) and devoting more emergency funds to cover the costs entailed by these measures.

In 2016, the Commission once again proposed a small change to the core Dublin regulation: although the point of entry would still determine which state was responsible for handling the asylum claim, in case a state faced a disproportionate number of asylum seekers, a "corrective allocation mechanism" would facilitate the transfer of applicants to states facing a lesser burden (Lehne 2018, 3). This proposal divided EU states into those who believed the Union should uphold its humanitarian commitments and those who felt that an obligatory quota system was unfair and that the solution was a stronger control of the external borders, and was eventually scraped. The 
inability to agree on this measure revealed once more a vast difference in capability among member states, as well as deficits in trust and cooperation.

In early 2016, the European Commission announced the proposal of reforming the Common European Asylum System, and especially its Dublin component (Grigonis 2016), which was supposed to be completed by December of that year. However, the inability to agree of a reform framework meant that the proposed comprehensive revision was postponed until the European Council of June 2018 (to which I will refer in the concluding section of the present article) and that measures finally adopted represented relatively minor changes to the previous provisions. In October 2017, the EU Council President Donald Tusk set the first half of 2018 (under the Bulgarian presidency) as the deadline to finalise the package of EU asylum reforms, following a series of meetings under the Maltese and Estonian presidencies where little progress was achieved (Lehne 2018). The only notable progress was the reform of the EU's asylum support agency EASO, based in Malta, tasked with monitoring how states implement EU asylum standards and rules (Nielsen 2017). The attempt by the Maltese presidency to broker a Dublin reform by which states opposed to accepting migrants would be able to trade off technical and financial support instead of hosting asylum seekers was a failure, as were attempts to revisit the reception conditions directive (where the main contentious point was the matter of access to the labour market), the qualifications regulation and the asylum procedures directive. However, despite such setbacks, the EU commissioner for migration, Dimitris Avramopoulos, declared in May 2017 that an agreement on the reform of the Dublin System could be achieved within a few months, admitting that the current system was unfair in terms of burden-sharing (Barigazzi 2017).

In November 2017, the European Parliament, which decried the lack of common solutions and condemned the practice of externalising borders by singing deals with Turkey or Libya, took the initiative and supported a reform of the Dublin system with a large cross-party majority. The EP insisted that this reform should take the form of a package approach to prevent member states from "cherry picking" which aspects they wish to discuss and which to ignore (EURACTIV 2018). In December 2017, the Commission put forward a road map for reaching an agreement on a comprehensive package of migration reforms by the summer of 2018 - most likely, at the European Union Summit in June 2018. 


\section{Concluding remarks: (small) steps towards reform and prospects for the future}

A series of findings presented at a June 2017 conference organised by the European Social Survey and the Migration Policy Group revealed that $72 \%$ of Europeans of all ages, education levels and political orientations, support a fair allocation of refugees based on the country's reception capacity (population size, GDP, employment rate, number of asylum applications) and regardless of its economic situation; a majority of them (56\%) remain in favour of proportional allocation even though this method could very well increase the number of asylum seekers present in their country (Huddleston and Mikaba 2017). These findings reveal a wide gap between opposing political attitudes (especially in some member states such as Hungary, which has been adamant in its refusal to accept any refugees on its territory) and more tolerant public perceptions - a gap that mirrors the divide at EU level between supranational institutions and member state governments.

The twelfth-hour agreement on immigration reform reached at the EU summit on June 28-29, 2018 is an attempt to bridge this gap and to avert a crisis that would have further destabilised the Union by throwing one of its backbones - Germany - into political chaos. Two weeks before the summit, chancellor Merkel's Bavarian government partners, the CSU, gave her what amounted to a political ultimatum: formulate a convincing reform plan that would reduce migration into Germany or they would abandon the coalition with Merkel's CDU and force her either to lead a minority government or resign (Saltz 2018; Carter 2018). Faced with dire circumstances, the German chancellor and her traditional partner, French president Emmanuel Macron, met before the Brussels summit to draft a list of proposals to be discussed during the official meeting of heads of state and government, which included a streamlined and more fair migrant distribution system among EU member states, as well as plans to strengthen the borders and target the causes of migration (Rickman 2018).

Events occurring days before the June EU summit showed that, although the scale of migration into Europe is only a fraction of what it was at the height of the crisis in the summer of 2015, the problem is far from being resolved: Italy's new far-right interior minister Matteo Salvini refused to allow the migrant rescue ship Aquarius, carrying 141 migrants from Libya and Eritrea, including 67 children, to dock in an Italian harbour, declaring that his country would not take in any more 
migrants. ${ }^{24}$ Eventually, the ship was finally allowed to dock in Malta and France, Germany, Portugal, Luxembourg and Spain agreed to each take in a share of its passengers. This incident clearly showed that the idea of burden-sharing, which the Commission hoped would be the basis for the reform of the asylum system, was not welcomed by countries like Austria, Hungary, Italy, Slovakia, Czech Republic, whereas France, Germany or Spain still insisted on the need for a common solution (Carter 2018).

Under those circumstances, Angela Merkel characterised the summit as the "make or break" moment for the European Union, while Hungarian Prime Minister Orban, in keeping with his earlier positions, declared that "the main issue is not migration, the issue is democracy in Europe" (Reuters 2018). The key issue to be dealt with at the summit was the reform of the Dublin regulation in such a way as to ease the pressure on southern EU countries and avoid the muchmaligned mandatory refugee quotas. Many of the previous Commission and Parliament proposals were discussed during the long and difficult negotiation process that eventually proved to be conducive to a compromise, since nearly everyone, in the words of an unnamed EU diplomat, "was almost equally unhappy with them" (Baczynksa 2018).

The final text of the agreement - which is more a reaffirmation of earlier principles than a comprehensive reform of any kind - was agreed after marathon negotiations on June 29, 2018. Its main points include: a commitment on the part of Commission to "continue and reinforce policy to prevent a return to the uncontrolled flows of 2015 and to further stem illegal migration on all existing and emerging routes"; an intensification of efforts to stop smuggling networks operating on the central Mediterranean route, especially from Libya and a support for Italy in this respect, including in matters of voluntary resettlement; efforts to fully implement the migrant deal with Turkey through the readmission agreement and bilateral readmission agreements so as to prevent new crossings from Turkey; cooperation with partners in the Western Balkans to prevent the development of new land routes, illegal immigration and increase border protection; a new approach based on shared member state actions for the disembarkation of those who are saved in search and rescue operations through regional disembarkation platforms outside the EU in cooperation with the UNHCR or the International Organisation for Migration; those who are saved

\footnotetext{
${ }^{24}$ Following elections in both Italy and Hungary in the first half of 2018, strong far-right anti-immigration parties assumed (or re-assumed, in Hungary's case) power in both countries, which proves that nationalistic anti-immigration discourse has not lost its appeal with voters.
} 
on the EU territory become the responsibility of member states through a shared effort and transferred to controlled centres in various member states on a voluntary basis so that it could be swiftly determined whether they are irregular migrants who are subject to return or refugees in genuine need of international protection; the allocation of the second tranche of financial aid to Turkey under the 2016 migrant deal; a closer partnership with Africa to prevent migration through a substantial economic and social transformation of the continent; a more significant external migration component; more financial support for member states to ensure effective control of the EU's external borders; the need for member states to take all necessary and legislative steps to counter secondary movements of asylum seekers among them and to cooperate with one another in that respect; more resources and an enhanced mandate for FRONTEX; the need to find a consensus for the reform of the Dublin Regulation based on "a balance of responsibility and solidarity", taking into account the progress made up to that point; the need to find a speedy solution to the entire reform package that the Council should adopt "as soon as possible" (CNN 2018; Blanchard and Kirkegaard 2018).

Based on the points listed above, it is evident that the measures agreed upon do not, in any way, represent the "comprehensive migration reform" that several EU officials had announced; if anything, they are a reaffirmation of earlier principles included in already approved pieces of legislation and, ultimately, an agreement for further talks with no clear deadline in sight. Probably the most important part of the new "migration deal" (as it was labelled by the press) was the one concerning relocation and resettlement to controlled centres on the territory of member states, which would be done on a strict voluntary basis, "without prejudice to the Dublin reform". This clearly indicates that the previous idea of quota relocation was abandoned in an effort to accommodate the position of countries vehemently opposed to it.

While the text agreed in Brussels in June 2018 does indicate some small progress on the path to an effective reform of the EU's migration and asylum system, it also reveals that the securitisation of the migration issue is probably stronger than ever, since many of the provisions included in the final draft discuss aspects such as border control, prevention of illegal migration and cooperation with third countries in matters of readmission and tackling the root causes of 
migration. ${ }^{25}$ If anything, the migration compromise is designed to set in motion the much-needed effective reforms to the EU's fragile immigration system. Any such reforms must be based on two pillars: efficient control over the Union's external borders and a new set of internal rules. As far as the former is concerned, the bases have been laid at the recent summit, yet FRONTEX should be given responsibility over the regional disembarkation platforms and it should cooperate with asylum processing centres to determine the validity of asylum claims based on a common, harmonised set of rules. Another efficient method for dealing with the question of refugee flows could be an alternative to traditional resettlement schemes and naturalisation policies: the EU may issue "humanitarian visas" to refugees transiting countries such as Turkey, Lebanon, Jordan, which would not only ensure a safe passage to the EU, but would also minimise the risk of resorting to smugglers or embarking on dangerous journeys (Welsh 2016).

Moreover, FRONTEX should also assume responsibility for integrating the national border guards into a coherent European force, because a centralised agency would be much better equipped to manage the EU's external frontiers (Lehne 2018). Concerning the latter, if the concept of quotas should be revisited, this should be done based on a bottoms-up approach to avoid the crisis triggered by the September 2015 situation; in addition, there should exist a complete mutualisation of costs associated with refugees admitted through the processing centres at the level of the EU, by which all countries should contribute to the common pool and any state that refuses to accept refugees should make a larger financial contribution than a state willing to take on a larger number of people (Blanchard and Kirkegaard 2018).

Regardless of how the immigration reform process will be finalised, one thing remains undisputed: issues of migration and asylum will continue to be central to European political debates, both at the supranational and national levels. Member states will not agree to completely relinquish control in favour of EU institutions in matters they consider crucial to their sovereignty and, for the foreseeable future, national contexts will continue to influence decisions made in Brussels, especially if the current rise of Eurosceptic, anti-immigrant parties that link opposition to European integration to opposition to immigration continues. At the same time, it is equally

${ }^{25}$ This aspect has been rather marginalised until now in discussions concerning immigration reform, yet any efficient changes in this respect need to address the combination of push and pull factors that determine people to migrate and to understand that, for instance, while it is true that today's refugees are, in most cases, pushed out of their countries by forces beyond their control, they are also closely intertwined with other migratory streams, particularly economic migrants or environmental migrants (Welsh 2016; Samaddar 2016). 
undisputed that Europe cannot face another migration crisis the same way it did the last time: divided, conflicted and indecisive; to do so would undoubtedly spell dark days ahead for the European project.

\section{References}

1. ABDOU, L. H. (2016) The Europeanization of Immigration Policies. In AMELINA, A., HORVATH, K., and MEEUS, B. (eds.) An Anthology of Migration and Social Transformation. European Perspectives. Dordrecht: Springer, pp. 105-120.

2. AMElinA, A., HORVATH, K. and MEEUS, B. (2016). Migration and Social Transformation: Interdisciplinary Insights and European Perspectives. In AMELINA, A., HORVATH, K., and MEEUS, B. (eds.) An Anthology of Migration and Social Transformation. European Perspectives. Dordrecht: Springer, pp. 1-13.

3. BACZYNKSA, G. (2018) EU Migration Dispute Heats Up again before June Summit. Reuters, May 7, 2018. [Online] Available from: https://www.reuters.com/article/us-europemigrants/eu-migration-dispute-heats-up-again-before-june-summit-idUSKBN1I81R5 [Accessed 15/08/2018]

4. BALCH, A. (2016) Immigration and the State. Fear, Greed and Hospitality. New York: Palgrave Macmillan.

5. BARIGAZZI, J. (2018) EU Closing in on Migration Reform, Says Commissioner. Politico, May 12, 2017. [Online] Available from: https://www.politico.eu/article/eu-closing-in-onmigration-reform-says-commissioner/ [Accessed 15/08/2018]

6. BLANCHARD, O. and KIRKEGAARD, J. (2018) Immigration Reform in Europe Needs External Border Controls, Respect for Sovereignty and Shared Costs. CEPR Policy Portal, July 4, 2018. [Online] Available from: https://voxeu.org/content/immigration-reform-europe [Accessed 16/08/2018]

7. CARTER, B. (2018) What Is the EU Preparing on Immigration? Euronews, June 26, 2018. [Online] Available from: http://www.euronews.com/2018/06/26/what-is-the-eu-preparing-onimmigration-euronews-answers [Accessed 16/08/2018]

8. CHERUBINI, F. (2015) Asylum Law in the European Union. London: Routledge Taylor\&Francis. 
9. CNN (2018) Text of the European Union Migration Deal. [Online] Available from: https://edition.cnn.com/2018/06/29/europe/eu-migration-deal-text-intl/index.html [Accessed $16 / 08 / 2018]$

10. COLLIER, P. (2013) Exodus. How Migration Is Changing Our World. New York: Oxford University Press.

11. COMTE, E. (2018) The History of the European Migration Regime. Germany's Strategic Hegemony. London and New York: Routledge Taylor\&Frances.

12. CRAIG, S. (2013). Struggling with EU Safe Country Practices in Asylum. In KORKUT, U. et al. (eds.) The Discourses and Politics of Migration in Europe, pp. 53-72.

13. DACYGIER, R. M. (2010) Immigration and Conflict in Europe. New York: Cambridge University Press.

14. DE GENOVA, N. (2017) Introduction. The Borders of "Europe" and the European Question. In DE GENOVA, N. (ed.) The Borders of “Europe”. Autonomy of Migration, Tactics of Bordering. Durham: Duke University Press, pp. 1-36.

15. DEMENY, P. (2006) Europe's Immigration Challenge in Demographic Perspective. In PARSONS, C. A. and SMEEDING, T. M. (eds.) Immigration and the Transformation of Europe. New York: Cambridge University Press, pp. 30-42.

16. DÜVELL, F. (2006) The Irregular Migration Dilemma: Keeping Control, Out of Control or Regaining Control? In DÜVELL, F. (ed.) Illegal Immigration in Europe. Beyond Control? New York: Palgrave Macmillan, pp. 3-13.

17. EISELE, K. (2016) EU Migration Policies and External Relations. In BESHAROV, D. J. and LOPEZ, M. H. (eds.) Adjusting to a World in Motion. Trends in Global Migration and Migration Policy. New York: Oxford University Press, pp. 188-208.

18. EURACTIV (2018) MEPs Hope to Break Deadlock on Migration Reform. [Online] Available from: https://www.euractiv.com/section/justice-home-affairs/news/meps-hope-to-breakdeadlock-on-migration-reform/ [Accessed 15/08/2018]

19. FEKETE, L. (2009) A Suitable Enemy. Racism, Migration and Islamophobia in Europe. New York: Pluto Books.

20. GEDDES, A. and SCHOLTEN, P. (2016) The Politics of Migration and Immigration in Europe. London: Sage. 
21. GEIGER, M. (2016) Identity Check: Smart Borders and Migration Management as Touchstones for EU Readiness and Belonging. In AMELINA, A., HORVATH, K., and MEEUS, B. (eds.) An Anthology of Migration and Social Transformation. European Perspectives. Dordrecht: Springer, pp. 135-150.

22. GRIGONIS, S. (2016) EU in the Face of the Migrant Crisis. Reasons for Ineffective Human Rights Protection. International Comparative Jurisprudence, 2, pp. 93-98.

23. HASSOURI, P. (2017) Challenging Established Categories and Exploring Intersections. A Critical Assessment of Common Notions in Migration Discourse. In JÜNEMANN, A., FROMM, N., and SCHERER, N. (eds.) Fortress Europe? Challenges and Failures of Migration and Asylum Policies. Wiesbaden: Springer, pp. 11-22.

24. HUDDLESTON, T. and MIKABA, P. (2017) Attitudes towards Immigrants in Europe: Myths and Realities. European Social Survey. [Online] Available from: https://www.europeansocialsurvey.org/docs/findings/IE_Handout_FINAL.pdf [Accessed $16 / 08 / 2018]$

25. JÜNEMANN, A., FROMM, N., and SCHERER, N. (2017) The Kaleidoscope of Migration. Theoretical Perspectives and Conceptual Considerations. In JÜNEMANN, A., FROMM, N., and SCHERER, N. (eds.) Fortress Europe? Challenges and Failures of Migration and Asylum Policies. Wiesbaden: Springer, pp. 1-10.

26. KARAMANIDOU, L. (2015) The Securitisation of European Migration Policies: Perceptions of Threat and Management of Risk. In LAZARIDIS, G. and WADIA, K. (eds.) The Securitisation of Migration in the EU. Debates since 9/11. New York: Palgrave Macmillan, pp. 37-61.

27. KHORY, K. R. (2012) Introduction. In KHORY, K. R. (ed.) Global Migration, Challenges in the Twenty-First Century. New York: Palgrave Macmillan, pp. 1-16.

28. KOOPMANS, R. et al. (2005) Immigration and Cultural Diversity in Europe. Minneapolis: University of Minnesota Press.

29. KORKUT, U., BUCKEN-KNAPP, G., and MCGARRY, A. (2013). Immigration and Integration Policies. In KORKUT, U. et al. (eds.) The Discourses and Politics of Migration in Europe, pp. 1-15.

30. LAZARIDIS, G. (2015) International Migration into Europe. From Subjects to Abjects. New York: Palgrave Macmillan. 
31. LAZARIDIS, G. and WADIA, K. (2015) Introduction. In LAZARIDIS, G. and WADIA, K. (eds.) The Securitisation of Migration in the EU. Debates since 9/11. New York: Palgrave Macmillan, pp. 1-18.

32. LEHNE, S. (2018) The EU Remains Unprepared for the Next Migration Crisis. Carnegie Europe, April 3, 2018. [Online] Available from: https://carnegieeurope.eu/2018/04/03/euremains-unprepared-for-next-migration-crisis-pub-75965 [Accessed 14/08/2018]

33. LYONS, K. and HUEGLE, N. (2010) European Union Immigration and the European Union. In SEGAL, U. A., ELLIOTT, D. and MAYADAS, N. S. (eds.) Immigration Worldwide. Policies, Practices and Trends. New York: Oxford University Press, pp. 437-448.

34. MARTINIELLO, M. (2006) The New Migratory Europe: Towards a Proactive Immigration Policy? In PARSONS, C. A. and SMEEDING, T. M. (eds.) Immigration and the Transformation of Europe. New York: Cambridge University Press, pp. 298-326.

35. MITSILEGAS, V. (2015) The Criminalisation of Migration in Europe. Challenges for Human Rights and the Rule of Law. Dordrecht: Springer.

36. MUNSTER, R. V. (2009) Securitizing Immigration. The Politics of Risk in the EU. New York: Palgrave Macmillan.

37. MURRAY, D. (2017) The Strange Death of Europe. Immigration, Identity, Islam. London: Bloomsbury.

38. NIELSEN, N. (2017) The Asylum Files: Deadlock and Dead Ends. EU Observer, December 27, 2017. [Online] Available from: https://euobserver.com/europe-in-review/139748 [Accessed 16/08/2018]

39. NIELSEN, N. (2018) EU States Tackle Dublin Asylum Reform 'Line by Line'. EU Observer, March 7, 2018. [Online] Available from: https://euobserver.com/migration/141236 [Accessed $16 / 08 / 2018]$

40. O’NIONS, H. (2014) Asylum - A Right Denied. A Critical Analysis of European Asylum Policy. Surrey: Ashgate.

41. ORRENIUS, P. M. and ZAVODNY, M. (2016) Irregular Migration in the European Union. European Policy Analysis, Issue 2, pp. 1-20.

42. PICKEL, G. (2018) Perceptions of Plurality: The Impact of the Refugee Crisis on the Interpretation of Religious Pluralization in Europe. In SCHMIEDEL, U. and SMITH, G. (eds.) Religion in the European Refugee Crisis. New York: Palgrave Macmillan, pp. 15-38. 
43. REUTERS (2018) EU Leaders Begin Migration Talks at Summit. [Online] Available from: http://www.euronews.com/2018/06/28/watch-live-eu-leaders-begin-migration-talks-atsummit [Accessed 15/08/2018]

44. RICKMAN, C. (2018) Macron and Merkel Meet to Discuss EU Immigration Reform. [Online] Available from: https://frenchly.us/macron-and-merkel-discuss-eu-immigration-reform/ [Accessed 16/08/2018]

45. ROOS, C. (2013) The EU and Immigration Policies. Cracks in the Walls of Fortress Europe. New York: Palgrave Macmillan.

46. SALTZ, J. (2018) Merkel's Battle for an EU Immigration Solution. Euronews, June 20, 2018. [Online] Available from: http://www.euronews.com/2018/06/20/merkel-s-battle-for-an-euimmigration-solution-euronews-answers [Accessed 16/08/2018]

47. SAMADDAR, R. (2017) A Post-Colonial Enquiry into Europe's Debt and Migration Crisis. Wiesbaden: Springer.

48. SCHEEL, S. (2017) "The Secret Is to Look Good on Paper": Appropriating Mobility within and against a Machine of Illegalization. In DE GENOVA, N. (ed.) The Borders of "Europe”. Autonomy of Migration, Tactics of Bordering. Durham: Duke University Press, pp. 37-63.

49. SCHMIEDEL, U. and SMITH, G. (2018) Introduction: Charting a Crisis. In SCHMIEDEL, U. and SMITH, G. (eds.) Religion in the European Refugee Crisis. New York: Palgrave Macmillan, pp. 1-13.

50. SQUIRE, V. (2015) The Securitisation of Migration: An Absent Presence? In LAZARIDIS, G. and WADIA, K. (eds.) The Securitisation of Migration in the EU. Debates since 9/11. New York: Palgrave Macmillan, pp. 19-36.

51. THE ECONOMIST (2016). More Neighbours Make More Fences. The Economist, Jan. 7, 2016. [Online] Available from: https://www.economist.com/graphic-detail/2016/01/07/moreneighbours-make-more-fences?fsrc=rss [Accessed 14/08/2018]

52. TRAUB, J. (2016) To Stay Open, Europe Needs to Close Its Doors. Foreign Policy, June 20, 2016. [Online] Available from: https://foreignpolicy.com/2016/06/20/to-stay-open-europeneeds-to-close-its-doors/ [Accessed 15/08/2018]

53. VINK, M. (2005) Limits of European Citizenship. European Integration and Domestic Integration Policies. New York: Palgrave Macmillan. 
54. VÖLKEL, J. C. (2017) When Interior Ministers Play Diplomats. Fatal Ambiguities in Europe's Securitised Migration Policies. In JÜNEMANN, A., FROMM, N., and SCHERER, N. (eds.) Fortress Europe? Challenges and Failures of Migration and Asylum Policies. Wiesbaden: Springer, pp. 83-104.

55. WELSH, J. (2016) The Return of History. Conflict, Migration and Geopolitics in the Twentieth-Century. Toronto: Anansi.

56. WIESBROCK, A. (2016) The Evolution of EU Migration Policies: Towards a Balanced, Comprehensive and Common Approach? In BESHAROV, D. J. and LOPEZ, M. H. (eds.) Adjusting to a World in Motion. Trends in Global Migration and Migration Policy. New York: Oxford University Press, pp. 159-187. 